Review

\title{
MURTA (Ugni molinae Turcz.): A REVIEW ON CHEMICAL COMPOSITION, FUNCTIONAL COMPONENTS AND BIOLOGICAL ACTIVITIES OF LEAVES AND FRUITS
}

Revisión
MURTA (Ugni molinae Turcz.): UNA REVISIÓN SOBRE COMPOSICIÓN QUÍMICA, COMPONENTES FUNCIONALES Y ACTIVIDADES BIOLÓGICAS DE LAS HOJAS Y FRUTO

\author{
Jéssica López $^{1 *}$, Antonio Vega-Gálvez ${ }^{2}$, Angela Rodríguez²; Elsa Uribe ${ }^{2,4}$, Cristina Bilbao-Sainz $^{3}$ \\ ${ }^{1}$ School of Food Engineering, Pontificia Universidad Católica de Valparaíso, Chile \\ ${ }^{2}$ Department of Food Engineering, Universidad de La Serena, La Serena, Chile. \\ ${ }^{3}$ Bioproduct Chemistry and Engineering, US Department of Agriculture, Albany, California 94710 \\ ${ }^{4}$ Instituto de Investigación Multidisciplinario en Ciencia y Tecnología, Av. Raúl Bitrán Nachary 1305, \\ Casilla 599, La Serena, Chile \\ * Corresponding autor E-mail: j.lopez.pasten@gmail.com
}

\section{RESUMEN}

Murta (Ugni molinae Turcz.) es una especie nativa del centro y sur de Chile. La planta ha despertado interés por el alto contenido de nutrientes esenciales y fitoquímicos beneficiosos relevantes para la salud humana. Entre estos fitoquímicos, una amplia variedad de antocianinas son los compuestos antioxidantes más importantes. Existen algunos estudios relacionados con la composición fitoquímica y con la actividad biológica de la fruta de murta, sin embargo, todavía faltan estudios clínicos donde se utilice la fruta. Este manuscrito revisa la composición nutricional y fitoquímica de las bayas y hojas de murta. Sin embargo, se requieren más antecedentes científicos para validar las propiedades de esta especie, a fin de lograr una apreciación real de todo el arbusto para el desarrollo de alimentos funcionales y nutracéuticos.

Palabras clave: compuestos fenólicos, antocianinas, actividad antibacteriana, actividad antioxidante, bayas y hojas de murta.

\section{ABSTRACT}

Murta (Ugni molinae Turcz.) is a native species from central and southern Chile. There is an increasing interest in the plant due to its high content of essential nutrients and beneficial phytochemicals to human health. In fact, the berries contain a wide variety of anthocyanins, which are the main antioxidant compounds. There are some studies on the phytochemical composition and biological activities of murta fruit, but human intervention studies using whole fruits are still lacking. This manuscript reviews the nutritional and phytochemical composition of murta berries and leaves. However, more scientific background is needed to validate the properties of this species so as to gain complete knowledge of the whole shrub in order to develop functional foods and nutraceuticals.

Key words: phenolic compounds, anthocyanins, antibacterial activity, antioxidant activity, murta berry and leaves.

Received: 17 April 2017. Accepted: 31 October 2017. 


\section{INTRODUCTION}

Ugni molinae Turcz. known as "Multilla", "Murta", "Mutilla", 'Myrtle berry", "Chilean cranberry" or "Chilean guava", is a deciduous wild growing shrub that belongs to the Myrtaceae family. Henceforth, this berry will be referred as murta. It grows in the southern regions in the coastal mountains of Chile, the Andean Mountain foothills, and also in some regions of Argentina and Bolivia (Hauser et al., 2014; Alfaro et al., 2014). Murta berries can be consumed during the summer as fresh fruits or used to produce jam, syrup, desserts and liquor (Seguel et al., 2000). In Chile, even before the arrival of the Spaniards in 1536, the indigenous population of the area used this fruit as part of their diet and for the production of alcoholic beverages (Barreau et al., 2016). As dried fruits, murta can be used in food preparations or herbal infusions (Puente-Díaz et al., 2013; Rodríguez et al., 2014).

Apart from its nutritional properties, murta fruit and leaves have been used for a long time as a medicinal plant by Chilean indigenous peoples, such as Mapuche, Puelche and Pehuenche, who used leave infusions to treat dysentery (Hauser et al., 2014) and urinary tract infections. Murta berries have also been used for its astringent and stimulant properties (Schreckinger et al., 2010). Some animal studies have revealed analgesic, antiaging and anti-inflammatory properties in leaves of Ugni molinae (Delporte et al., 2007). The beneficial properties of extracts obtained from murta are partly due to the presence of different phenolic compounds (Romaní et al., 1999). Murta berries have a rich and diversified composition of bioactive compounds with health-promoting properties that have been intensively studied (Rodríguez et al., 2014). The relatively high content of polyphenolic compounds found in murta berries could be used as a new potential source of antioxidants (Puente-Díaz et al., 2013). In addition, these berries can be considered as an important source of vitamins, minerals and dietary fiber (Ah-Hen et al., 2013).

Due to an increase in the commercial value of murta in the domestic market, the Chilean Institute of Agricultural Research (INIA) developed a program in 1996 aimed at studying the domestication of this species, consisting of the collection of wild germplasm and the development of protocols for the regeneration and multiplication of plants, including the evaluation of the agronomic potential of these fruits (Seguel et al., 2000; Alfaro et al., 2013). INIA researchers carried out the molecular characterization of the wild germplasm collected in order to study the genetic diversity of this species, so as to complete its phenotypic and agronomic characterization (Alfaro et al., 2013). This review article covers the most important aspects of murta (Ugni molinae) berry including the composition and biological activities.

\section{BOTANICAL BACKGROUND}

Murta is an aromatic species belonging to the Myrtaceae family that typically dwells near the coastal and pre-Andean mountains of South America. It can also grow in subtropical regions, such as the Juan Fernández Island, but it can even grow in relatively desolate areas, such as sites of old lava flows, which indicates that it is a versatile plant (Schreckinger et al., 2010; Retamales et al., 2014). Some specimens of murta are also found in western Argentina, and certain regions of Bolivia (Scheuermann et al., 2008).

In Chile, murta grows in an area between southern Talca (Maule Region) (34 $41^{\prime}-36^{\circ} 33^{\prime}$ S) and Palena (Coyhaique Region) $\left(43^{\circ} 15^{\prime}-43^{\circ} 45^{\prime}\right.$ S) (Fig. 1C). It is known as "murta" in the zones of Valdivia and Chiloé, as "murtilla" in Concepción surroundings and as "uñi" by Mapuche people (Fredes, 2009; Retamales et al., 2014).

This species was identified and classified for the first time by Western botanists in 1844 (Rubilar et al., 2006). There are two new murta plant varieties grown in Chile, named as South pearl-INIA and Red pearl-INIA (Ah-Hen et al., 2013). Different ecotypes of this plant develop a variety of fruit colors including soft green, yellow, fuchsia (purplish), light and dark red (Scheuermann et al., 2008).

Murta is a wild rounded shrub (Fig. 1A) reaching up to 2 meters high. The plant has opposite leaves of about $1.7 \mathrm{~cm}$ long, which are generally ovoid and pointed. The plant produces a small globoid berry (Fig. 1B) that develops on a seasonal basis from March to May (Alfaro et al., 2014). Fruit equatorial diameter ranges from 0.71-1.31 cm (Alfaro et al., 2013), while weight ranges from 0.25 and $0.40 \mathrm{~g}$ The number of seeds per fruit varies greatly depending on the region in which the plant grows, with an average of $16.08 \pm 10$ seeds per fruit (Torres et al., 1999).

The characteristic aroma of murta berries may be described as fruity, combining the sweetness of a strawberry (Fragaria $\times$ ananassa ) with the pungency of a guava (Psidium guajava L.), and the texture of a dried blueberry (Vaccinium corymbosum L. ) with floral note due to volatile compounds similar to those found in many aromatic tropical and traditional fruits widely consumed around the world (Ah-Hen et al., 2013). 


\section{COMPOSITIONAL CHARACTERIZATION}

Many factors affect the physicochemical properties of murta berries, including cultivar/ genotype, altitude, environmental conditions (climate, light, temperature, soil type and other conditions), etc. (Alfaro et al., 2013). There is an apparent hybridization in murta, which has given rise to the generation of numerous ecotypes. This suggests the existence of a high variability in the physicochemical parameters of the fruit (Torres et al., 1999). Moreover, the stage of maturity that affects the overall nutritive quality of murta berries also depends on the agroecological zone where the plants grow. Ripening lasts from mid-February to mid-March in the Maule Region $\left(34^{\circ} 41^{\prime}-36^{\circ} 33^{\prime}\right.$ S); from March to April in the Araucanía Region (location 37³5'393' S); and from April to May in the Los Lagos Region (location $40^{\circ} 15^{\prime}-44^{\circ} 14^{\prime}$ S), especially in Chiloé Island (Fig. 1C) (Torres et al., 1999).

The nutritional composition of murta berries is shown in Table 1. Sugars are among the most important compounds that determine fruit quality. During the early period of berry growth, the fruit accumulates sucrose (Conde et al., 2007). However, glucose and fructose content increase with ripening. At the ripeness stage, the fruit produces a disaccharide

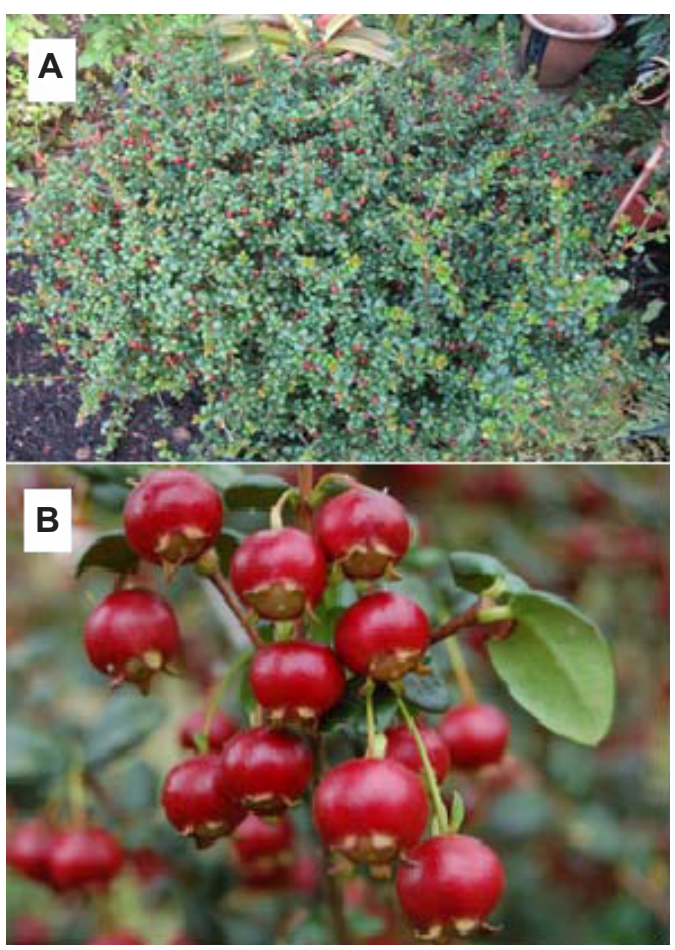

Fig. 1. (A) Murta shrub; (B) Murta (Ugni molinae) berries. (sucrose) and it is transformed into molecules of two monosaccharides (glucose and fructose), increasing its sugar concentration. The highest soluble solid content $\left(10-27^{\circ}\right.$ Brix) was found in the berries grown in Region del Maule (Chile) and this berries contain a high amount of dietary fiber (20.0\%) (González, 2009).

Another important component of murta is pectin, which is a valuable functional food ingredient widely used as gelling, emulsifying and stabilizing agent. Nowadays, its high content of pectin (0.32-1.14\%) allows preparing jam, jellies, infusions and liquor from this fruit. A fraction of this pectin is of high molecular weight, low neutral sugar content, and high degree of methoxylation, which increases the potential use of murta berries (Taboada et al., 2010). There are only a few reports regarding the content of vitamins and minerals in murta fruit. Moraga (2008) found that murta berries contain 4.53-12.55 $\mathrm{mg}$ of vitamin C (Vit. C) in $100 \mathrm{~g}$ of fresh berries. while Merino (2002) and Schmidt-Hebbel (1990) found calcium, phosphorus and potassium in murta berries.

The content of vitamin $C$ in murta is very low but it influences on the acceptance and palatability of this fruit on consumers, since it has a high antioxidant power, which becomes protective of tissues and cells of our body that are helpful for development of strong connective tissues and provides protection to the immune system against attacks of some pathogenic microorganisms, among others (Iqbal et al., 2004). More than $85 \%$ of Vit. C in human diets is supplied by fruits and vegetables (Davey et al., 2000; Lee and Kader, 2000) like the berries.

Calcium $(\mathrm{Ca})$ is an essential mineral for human health, partaking in the biological functions of several tissues (musculoskeletal, nervous and cardiac system, bones and teeth, and parathyroid gland). In addition, Ca may act as a cofactor in enzyme reactions (fatty acid oxidation, mitochondrial carrier for ATP, etc.) and it is involved in the maintenance of the mineral homeostasis and physiological performance in general (Morgan, 2008). Phosphorus (P) is closely related to Calcium homeostasis and also related to bone and teeth formation and the majority of the metabolic actions in the body, including kidney functioning, cell growth and the contraction of the heart muscle (Renkema et al., 2008). Potassium (K) plays a role in the maintenance of the balance of the physical fluid system and assisting nerve functions through its role in the transmittance of nerve impulses. It is also related to heart activity muscle contraction (Lambert et al., 2008). Unfortunately, there is still no information about the mineral content of murta. 
Table 1. Compositional characterization of murta.

\begin{tabular}{|c|c|c|c|}
\hline Type & Nutrient & Per $100 \mathrm{~g}$ & References \\
\hline \multirow{12}{*}{ Proximate } & Water, $\mathrm{g}$ & $76.95-84.14$ & Taboada et al., 2010; Ah-Hen et al., 2012; 2013 \\
\hline & Calories, Kcal & 75 & Merino, 2002 \\
\hline & ${ }^{\circ}$ Brix & $6.5-28$ & Scheuermann et al., 2008; Ah-Hen et al., 2013; \\
\hline & $\mathrm{pH}$ & $3.50-5.2$ & Ah-Hen et al., 2012; 2013; Scheuermann et al., 2008 \\
\hline & Acidity, meq $\mathrm{NaOH}$ & $0.91-1.51$ & Durán et al., 2014 \\
\hline & Protein, $g$ & $1.15-17.98$ & Taboada et al., 2010; Ah-Hen et al., 2012; 2013 \\
\hline & Ash, $g$ & $0.60-0.89$ & Ah-Hen et al., 2012 \\
\hline & Total lipid, g & $0.30-0.85$ & Ah-Hen et al., 2012: 2013 \\
\hline & Crude fibre, $g$ & $2.50-3.24$ & Ah-Hen et al., 2012 \\
\hline & Carbohydrate, $g$ & $17.6-19.4$ & Ah-Hen et al., 2012 \\
\hline & Dietary fiber, $g$ & 21.6 & Durán et al., 2014 \\
\hline & Pectins, g & $0.32-1.14$ & Torres et al., 1999 \\
\hline \multirow{10}{*}{ Sugars } & Total sugars, $g$ & 58.2 & Torres et al., 1999 \\
\hline & Sucrose, $g$ & $3.43-12.1$ & Scheuermann et al., 2008; Gironés-Vilaplana et al., 2014 \\
\hline & Glucose, $\mathrm{g}$ & $1.45-1.88$ & Scheuermann et al., 2008; Gironés-Vilaplana et al., 2014 \\
\hline & Fructose, $g$ & $2.42-4.07$ & Scheuermann et al., 2008; Gironés-Vilaplana et al., 2014 \\
\hline & Galacturonic acid, $g$ & 24.3 & Taboada et al., 2010; Gironés-Vilaplana et al., 2014 \\
\hline & Arabinose, $g$ & 4.8 & Taboada et al., 2010; Gironés-Vilaplana et al., 2014 \\
\hline & Galactose, g & 4.5 & Taboada et al., 2010; Gironés-Vilaplana et al., 2014 \\
\hline & Rhamnose, $g$ & 0.8 & Taboada et al., 2010; Gironés-Vilaplana et al., 2014 \\
\hline & Xylose, $g$ & 2.1 & Taboada et al., 2010; Gironés-Vilaplana et al., 2014 \\
\hline & Mannose, g & 1.2 & Taboada et al., 2010; Gironés-Vilaplana et al., 2014 \\
\hline \multirow{3}{*}{ Minerals } & Calcium, mg & 90 & Merino, 2002; Schmidt-Hebbel et al., 1990 \\
\hline & Phosphorus, mg & 20 & Merino, 2002; Schmidt-Hebbel et al., 1990 \\
\hline & Potassium, mg & 116 & Merino, 2002; Schmidt-Hebbel et al., 1990 \\
\hline Vitamins & Vitamin C, mg & $4.53-12.55$ & Moraga, 2008 \\
\hline
\end{tabular}

Finally, murta seed oil is rich in linoleic acid. The composition of the fatty acids present in the seed oil has a high degree of unsaturation. It has a high content of linoleic acid but it does not contain linolenic acid (Torres et al., 1999), which means that these seeds could be a potentially good source of edible oil and may become a dietary supplement of good quality.

\section{BIOACTIVE COMPOUNDS}

The chemical composition of murta varies depending on climatic conditions during growth. Extreme climate conditions promote polyphenol synthesis (Schreckinger et al., 2010). The phytochemical composition of murta includes a wide variety of phenolic compounds in the leaves and fruits as well as pentacyclic triterpene acids (alphotolic, corosolic, and asiatic acid) in the leaves (Table 2). Phenolic compounds are categorized into classes depending on their structure, and subcategorized within each class according to the number and position of the hydroxyl group and the presence of other substituents (JimenezGarcia et al., 2013).

The main phenolic compounds in berries are flavonoids (anthocyanins, flavonols, flavanols), condensed and hydrolyzable tannins, stilbenoids (resveratrol), and phenolic acids. A study conducted by Alfaro et al. (2014) showed that the phenolic compounds in murta fruit possess antioxidant and antimicrobial activity.

Besides, there are 24 volatile compounds of the murta fruit aroma that have been elucidated, of which the major components are methyl 2-methyl butanoate, ethyl butanoate, ethyl 2-methyl butanoate, methyl hexanoate, ethyl hexanoate, methylbenzoate, and ethyl benzoate are (Schreckinger et al., 2010).

\section{Anthocyanins}

Anthocyanins are a group of red, purple, violet and blue water soluble polyphenolic plant pigments widely distributed in berry fruits, which can act as antioxidants or free radical scavengers, thus preventing oxidative stress (Gorinstein et 


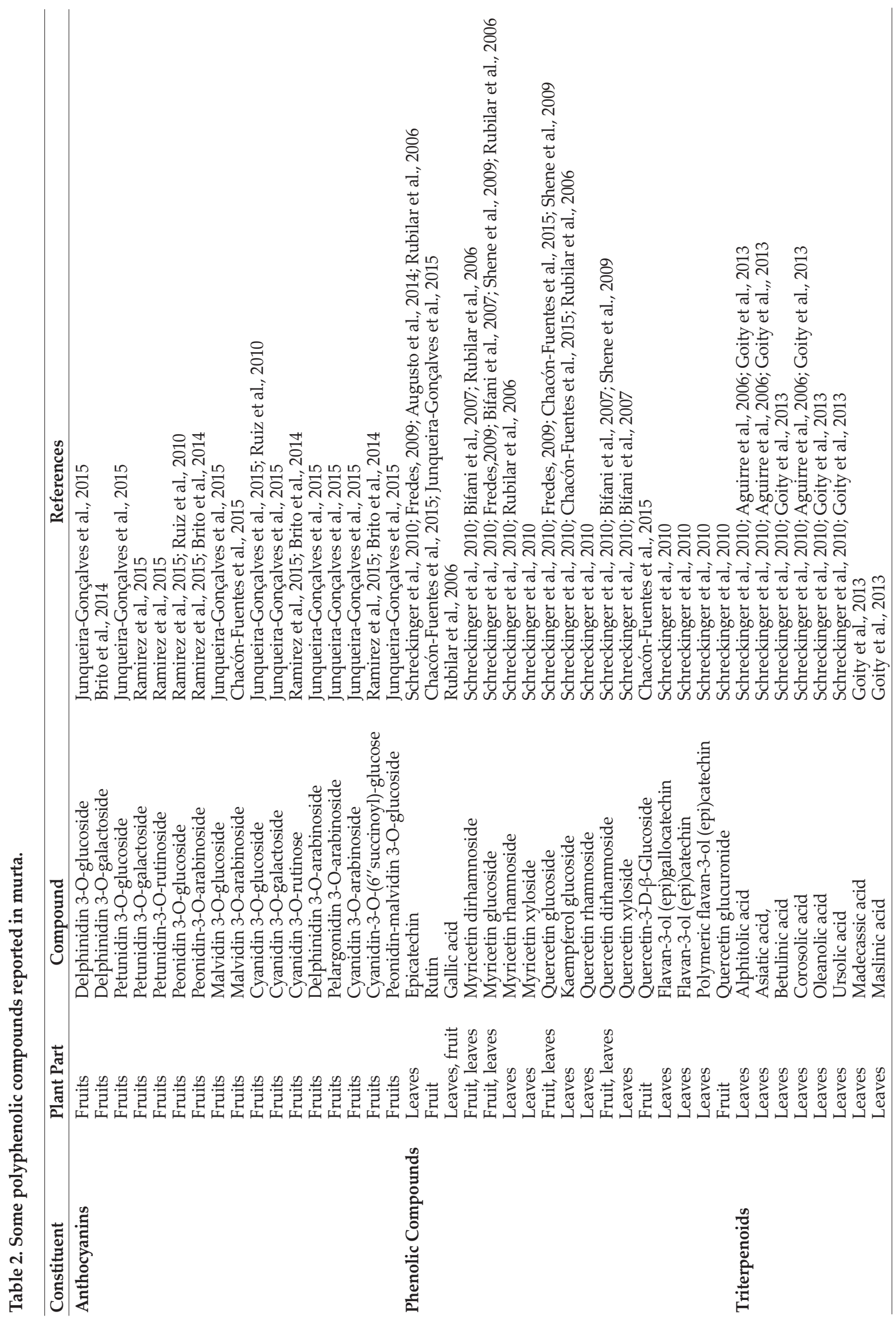


al., 2013; Brito et al., 2014) and cardiovascular disease risk (Junqueira-Gonçalves et al., 2015). Anthocyanins are also of technological interest due to their impact on the sensorial characteristics of food products.

Anthocyanins in murta berry fruits were accurately detected and identified using HPLC with UV-visible detection and high resolution time of flight mass spectrometry (HR-ToF-MS). The anthocyanins identified in the berries were mainly 3-O-glycoside conjugates and their derivatives (Brito et al., 2014). In addition Rubilar et al. (2011) identified cyanidin-3-glucoside and peonidin-3O-glucoside. Cyanidin-3-glucoside and peonidin3 -glucoside reach a total concentration of about 1 $\mu$ mol g-1 of dry matter (Ruiz, 2008).

\section{Other phenolic compounds}

Murta berries also have high contents of other phenolic compounds, but these levels are lower than those of anthocyins. The content of flavonols composition has been the subject of many studies. The amount of flavonols observed in murta fruit is two times higher than those in maqui (Aristotelia chilensis) and calafate (Berberis microphylla) fruits, being quercetin derivatives the most abundant flavonol (Ruiz et al., 2010). Shene et al. (2009) reported myricetin glucoside, quercetin glucoside, quercetin glucuronide and quercetin dirhamnoside in a 50\% water/ethanol murtilla fruit extract (Alfaro et al., 2014). Twelve flavonol compounds have been identified in murta berries (Table 2). The highest amounts of these compounds correspond to caffeic acid-3glucoside, quercetin-3-glucoside and quercetin. Peña-Cerda et al. (2016) identified 92 phenolic compounds in murta leaves and reported that gallic acid, myricetin, and quercetin were the most abundant ones.

Caffeic acid is one of the most common phenolic acids in fruits and grains. It is also present in dietary supplements for human consumption. Some glycosylated derivatives of caffeic acid are responsible for different biological activities, such as suppression of humoral and cellular immunity (Junqueira-Gonçalves et al., 2015).

Quercetin is one of the most abundant flavonols in the human diet and it has both chemical and biological properties (JunqueiraGonçalves et al., 2015).. In recent times, many of its benefits for health have been confirmed, including protection against various forms of cancer, cardiovascular diseases and neurodegenerative diseases (Junqueira-Gonçalves et al., 2015). Studies have shown that quercetin also exhibits anti-inflammatory, antibacterial and relaxing muscle activities (Erlund, 2004). Furthermore, this compound has been described as a potent competitive inhibitor of certain cytochromes P450 enzymes and sulfotransferases (Harbone and Williams, 2000; Junqueira-Gonçalves et al., 2015), a potent anticancer agent in human studies (ShihLi et al., 2006) and a strong antioxidant that can contribute to the prevention of atherosclerosis (Junqueira-Gonçalves et al., 2015). In addition, it has been demonstrated that it reduces the carcinogenic activity of several cooked food mutagens, enhances the anti-proliferative activity of anticancer agents, and inhibits the growth of tumor cells (Junqueira-Gonçalves et al., 2015).

Other minor bioactive compounds in murta berries were rutin, gallic acid, quercitin, luteolin, kaempferol, kaempferol-3-glucoside, luteolin-3-glucoside, p-coumaric acid and myricetin. Kaempferol is considered as a powerful antioxidant, with beneficial effects that include anti-tumor, anti-inflammatory, and anti-ulcer activity (Junqueira-Gonçalves et al., 2015). Quercitin and rutin have shown strong antioxidant and antibacterial effects, which may protect the cells of the colon (Junqueira-Gonçalves et al., 2015). In addition, there is evidence that quercitin decreases phototoxicity of hypericin and fagopyrin, which are substances found in St. John's wort (Hypericum perforatum L.) and buckwheat (Fagopyrum esculentum Möench), respectively (Junqueira-Gonçalves et al., 2015).

Previous works have shown that murta leaf extracts contain hydroxybenzoic acids, flavan3-ols, glycosylated flavonols (Rubilar et al., 2006) and triterpene acids (Aguirre et al., 2006). The analgesic properties of murta infusions are associated with both flavonoid glucosides and triterpenoids (Delporte et al., 2007). Rubilar et al. (2011) have conducted an analysis of leaf extracts of this berry, describing hydrobenzoic acid derivatives, quercetin dirhamnoside and myricetin rhamnoside as the main compounds, and several others that were not identified.

\section{Triterpenoids}

The phytochemical composition of murta leaves includes pentacyclic triterpene acids, such as alphotolic, corosolic, ursolic and asiatic acids (Schreckinger et al., 2010). Triterpene acids present in murta leaves possess a potent antiinflammatory activity, which is similar to that of synthetic non-steroidal anti-inflammatory drugs. Several recent reports on the topical antiinflammatory activities of plant extracts have related the anti-inflammatory properties of plant extracts with the presence of triterpenoids, and more specifically to the very widespread and relatively abundant ursolic acid (Banno et al., 2004; Banno et al., 2005; Aguirre et al. 2006).

In the last fifteen years, interest in pentacyclic 
triterpenoids has revived. Aguirre et al, (2006) have contributed to the knowledge that several $2 \alpha$-hydroxy pentacyclic triterpene acids present in murta leaves have an interesting topical antiinflammatory activity. Wen et al. (2008) stated that pentacyclic triterpenoids represent a new class of glycogen phosphorylase "a" (GPa) inhibitors, an enzyme that has a fundamental role in the release of glucose into the bloodstream through the glycogenolysis (Aguirre et al., 2006).

\section{AROMA AND VOLATILE COMPOUNDS}

Berries are receiving considerable attention in the aroma industry because of their flavor and aroma, which are frequently considered as exotic and stimulate consumption worldwide. Table 3 shows the concentration of the different volatile compounds identified in fresh murta fuit. Schreckinger et al. (2010) found that the main components in the aroma of murta fruit were methyl 2-methyl butanoate, ethyl butanoate, ethyl 2-methyl butanoate, methyl hexanoate, ethyl hexanoate, methylbenzoate, and ethyl benzoate. Scheuermann et al. (2008) and Schreckinger et al. (2010) reported t methyl 2-methyl butanoate, ethyl butanoate, methyl pentanoate, ethyl 2-methyl butanoate, methyl hexanoate, $\alpha$-pinene, ethyl hexanoate, 1,8-cineole, D-limonene and methyl benzoate as common volatile constituents in different ecotypes of the plant (Table 3). Furthermore, Scheuermann et al. (2008) identified twenty four volatile aromatics in the murta fruits; these compounds were absorbed onto a Porapak $\mathrm{Q}$ column, where the filling material is a porous polymer of copolymers of ethyl vinybenzene and divinylbenzene, they reported the major volatile constituent is methyl hexanoate (97.2-250.5 $\mu \mathrm{g} \mathrm{kg}^{-1}$ fresh weight), and is found in different ecotypes of murta.

The murta aroma is considered a mixture of tropical and traditional aroma constituents (Scheuermann et al., 2008). Some volatile compounds, such as butyl acetate, ethyl 2-methyl butanoate, ethyl hexanoate, hexyl acetate methyl octanoate, ethyl benzoate, limonene and benzaldehyde, are present in the aroma of traditional fruits like apple, apricot, peach and pear. Nevertheless, a study conducted by Scheuermann et al. (2008) showed that there are other aroma compounds, such as ethyl 2-methyl propanoate, methyl and ethyl pentanoate, ethyl

Table 3. Aroma volatile compounds released from four ecotypes of murta fruit (Scheuermann et al., 2008).

\begin{tabular}{lc}
\hline Volatile compound & $\mu \mathrm{g} / \mathrm{kg}$ fresh weight \\
\hline Methyl butanoate & $\mathrm{ND}$ \\
Ethyl 2-methyl propanoate & $4.7-3.4$ \\
Methyl 2-methyl butanoate & $127.1-73.3$ \\
Ethyl butanoate & $143.3-20.8$ \\
n-Butyl acetate & $9.0-1.3$ \\
Methyl pentanoate & $19.9-6.9$ \\
Ethyl (2E)-but-2-enoate & $27.6-2.3$ \\
Propan-2-yl butanoate & $8.3-1.7$ \\
Ethyl 2-methyl butanoate & $80.0-4.1$ \\
Ethyl 3-methyl butanoate & $38.5-13.0$ \\
3-Methylbutyl acetate & $3.9-0$ \\
Ethyl pentanoate & $8.9-1.1$ \\
Methyl hexanoate & $250.5-97.2$ \\
Benzaldehyde & $9.6-5.3$ \\
$\alpha$-Pinene & $55.9-3.6$ \\
Ethyl hexanoate & $127.7-7.2$ \\
Hexyl acetate & $7.0-0$ \\
1,8-Cineole & $9.5-7.1$ \\
D-Limonene & $72.7-2.6$ \\
4-Methoxy-2,5-dimethyl-furan-3-one & $34.8-5.0$ \\
Methyl benzoate & $158-5.5$ \\
Methyl octanoate & $8.5-5.1$ \\
Ethyl benzoate & $98.8-6.4$ \\
Ethyl octanoate & $\mathrm{ND}$ \\
\hline
\end{tabular}

ND: not detected. 
(2E)-but-2-enoate, ethyl 2-methyl butanoate, ethyl 3-methyl butanoate, methyl and ethyl benzoate, which are present in the aroma of tropical fruits like pitanga (Eugenia uniflora L.), umbu-caja (Spondias citherea), camucamu (Myrciaria dubia), araca-boi (Eugenia stipitata), cupuacu (Theobroma grandiflorum), murici (Byrsonima crassifolia L., Rich), cashew apple (Anacardium occidentale L.) and mango (Mangifera indica).

\section{ANTIOXIDANT CAPACITY ASSESSEMENT}

Nowadays, several scientific studies have demonstrated that regular intake of berries would reduce the risk of development and/or progression of several chronic diseases, including cardiovascular diseases, neurodegenerative, and certain forms of cancer (Seeram, 2008; Basu et al., 2010). Nevertheless, there are few studies on native South American berries. A wide variety of methods has been applied to the study of the radical-scavenging activity, and the antioxidant activity of murta berries. Table 4 summarizes the different values obtained using different methods. The ABTS (2,2'-azino-bis(3- ethylbenzthiazoline6-sulphonic acid) method resulted in higher values than DPPH (2, 2-diphenylpicrylhydrazyl) assay (Augusto et al. 2014). The obtained antioxidant and oxygen radical absorbance capacity of fresh murta berries are 2.4-45.6 and 1.3-16.2 mmol Trolox equivalent (TE) $100 \mathrm{~g}^{-1}$ dried matter, respectively (Rodriguez et al., 2014).

The antioxidant activity of murta is also greater than that observed in Chilean maqui and calafate berries (Alfaro et al., 2014). The potential of these berries is very promising; therefore, special attention should be given to their study by researchers and agro-entrepreneurs.

Phenolic compounds act as exogenous antioxidant systems, composed of molecules mainly from the diet, and are proposed to protect against oxidative damage by oxygen-derived free radicals and reactive oxygen species (ROS) (Lambert et al., 2008). The ROS are involved in the mechanism that contributes to endothelial dysfunction and other metabolic disorders (Foncea et al., 2000). Therefore, the antioxidant capacity of natural phenolic compounds could reverse these damages. The molecular mechanisms of the antioxidant property of phenols and flavonoids have not yet been fully elucidated, and are still a matter of considerable debate. However, it has been suggested that the ability of these compounds to partition in cell membranes and the resulting restriction on their fluidity could critically hinder the diffusion of the ROS, thereby decreasing the kinetics of free radical reactions (Arora et al., 2000).

The high antioxidant capacity of berries is the most widely studied attribute among the biological properties of the fruit (Skrovankova et al., 2015). In fact, one of the ways through which the harmful effects of oxidative stress can be prevented and counteracted is the daily consumption of natural antioxidants, like those of murta.

The antioxidant activity of bioactive constituents of murta berries has been assessed by in vitro assays measuring the ability to reduce and trap free radicals; their potential as antioxidant is usually measured by comparing it to that of a reference substance, usually Trolox (trade name of 6-hydroxy-2,5,7,8-tetramethylchroman-2-carboxylic acid, derivative of vitamin E) (Paredes-López et al., 2010). A great diversity of methods has been applied to study both the radical-scavenging activity as well as the antioxidant activity of berry phenolic compounds, resulting in great

Table 4. Antioxidant capacity of murta.

\begin{tabular}{lcl}
\hline Method & Trolox equivalent & \multicolumn{1}{c}{ Reference } \\
\hline DPPH & $76.48-134.35\left(\mu \mathrm{mol} \mathrm{g}^{-1}\right) \mathrm{d} . \mathrm{m}$. & Augusto et al., 2014. \\
& $2367-45656\left(\mu \mathrm{mol} 100 \mathrm{~g} \mathrm{~g}^{-1}\right) \mathrm{d} . \mathrm{m}$. & Rodríguez et al., 2014. \\
ABTS & $157.04-293.99\left(\mu \mathrm{mol} \mathrm{g}^{-1}\right) \mathrm{d} . \mathrm{m}$. & Augusto et al., 2014. \\
ORAC & $6903-10770\left(\mu{\left.\mathrm{mol} 100 \mathrm{~g}^{-1}\right) \mathrm{f} . w .}\right.$ & Speisky et al., 2012. \\
& $1331-16225\left(\mu{\left.\mathrm{mol} 100 \mathrm{~g}^{-1}\right) \mathrm{d} . \mathrm{m} .}\right.$ & Rodríguez et al., 2014. \\
SDS-L & $8.06-23.80\left(\mu \mathrm{mol} \mathrm{mg}^{-1}\right) \mathrm{d} . \mathrm{m}$. & Peña-Cerda et al., 2016. \\
FRAP & $1.73-4.76\left(\mathrm{mg} \mathrm{g}^{-1}\right) \mathrm{f} . \mathrm{w}$. & Gómez-Guillén et al., 2007. \\
TEAC & $81.10\left(\mu \mathrm{mol} \mathrm{g}^{-1}\right) \mathrm{d} . \mathrm{m}$ & Ramirez et al., 2015. \\
\hline
\end{tabular}

ORAC: oxygen radical absorbance capacity; ABTS: 2,2'-azinobis(3-ethylbenzothiazoline-6-sulfonic acid; DPPH: 2,2-diphenyl-1-picrylhydrazil; SDS-L: Sodium dodecyl sulfate-linoleic acid; TEAC: Trolox equivalent antioxidant capacity; d.m.: dry matter; f.w.: fresh weight. 
differences in the outcome (Heinonen, 2007). The antioxidant capacity of murta has been studied using some assays like oxygen radical absorbance capacity (ORAC) method, ferric-reducing/ antioxidant power (FRAP) method, and 2, 2-diphenylpicrylhydrazyl (DPPH) (Peña-Cerda et al., 2016), 2,2'-azinobis(3-ethylbenzothiazoline-6sulphonic acid (ABTS+), among others (ParedesLópez et al., 2010).

The ORAC assay has been used in the analysis of pure substances, mixture of natural antioxidants and also in biological tissues. Free radicals, which are highly reactive species, can cause chain reactions, and also oxidative damage to biological macromolecules. These reactions are generated during cellular respiration, giving rise to radicals, such as hydroxyl $\left(\mathrm{OH}^{\circ}\right)$ and superoxide $\left(\mathrm{O}_{2}^{*}\right)$ (Dontha, 2016). Antioxidants are the main organic defense against these species, and include enzymes such as catalase, and non-enzymatic compounds such as vitamin $\mathrm{E}, \mathrm{C}, \beta$-carotene, bilirubin, glutathione, which are generally consumed in the diet or as supplements. To know the level of circulating antioxidants, it is necessary to have a number of methods to establish radical trapping antioxidant capacity. Most of these methods determine antioxidants that are water-soluble. These include ORAC assays for measuring both the time and percentage of damage caused by the free radical $(\mathrm{AAPH} \bullet$ ) to a fluorescent protein (R-ficoeritrina), manifesting its integrity in fluorescence intensity (Avello and Pastene, 2004). The highest ORAC values of fruits range from 10.0-25.0 mmol TE $100 \mathrm{~g}^{-1}$ fresh weight, including murta (Speisky et al., 2012).

DPPH is a rapid, inexpensive, convenient, and an accurate method to evaluate antioxidant activity. DPPH solutions have a violet color, and the delocalized unpaired electron is responsible for the strong absorption. Reduction reactions can be seen as decolorization. Results can be expressed as $\mathrm{EC}_{50}$ (concentration of antioxidant that reduces $50 \%$ of the DPPH radical) or percentage of decolorization. The DPPH is a longlived radical, and it is likely that the antioxidant response of biologically relevant antioxidants is different from that with the DPPH radical (Celli et al., 2014).

The FRAP assay was introduced by Benzie and Strain (1996) and is based on a change in the oxidation state of iron under low $\mathrm{pH}$. The $\mathrm{pH} 3.6$ required for this analysis improves iron insolubility, although it could also decrease the ionization potential of some compounds needed for the electron transfer reaction. In general, antioxidant capacity measured by FRAP is poorly correlated to other assays, such as DPPH and ORAC (Celli et al., 2014). Ultimately, the antioxidant activity in murta fruits has been related to high polyphenol levels (Alfaro et al., 2013). High levels of flavonoids like flavan-3ols (e.g. catechin and epicatechin), along with the anthocyanins cyanidin-3-glucoside and peonidin-3-glucoside could be responsible for the high antioxidant activity observed in murta berry (Alfaro et al., 2013).

\section{HEALTH BENEFITS}

Murta fruit is known to relieve circulation disorders and increase visual acuity, especially at night. Furthermore, mastication of fresh fruit without skin is useful to treat conditions of the mouth, such as thrush and stomatitis (Suwalsky and Avello, 2014).

Information from tradition coincides with the results of preliminary phytochemical studies, since polyphenolic compounds, such as flavonoids and tannins, have astringent and potentially antioxidant activity (Avello and Pastene, 2004; Arancibia-Radich et al., 2016). Murta possesses a complex blend of polyphenols with a wide distribution of molecular weights. Altogether, gallic tannins can be hydrolyzed to gallic acid, which partnered with flavonoids and catechins, contributing significantly to raise the antioxidant capacity of the plasma (Avello and Pastene, 2004).

The antimicrobial and insecticide activities of vegetables are important in defending the plant itself and the projection of an applicable use against pathogens in various areas. For example, in the search for new antimicrobial drugs in the conservation of various products and as allelochemicals (non-nutritional secondary metabolites produced by living organisms) (Avello et al., 2009).

Murta is a species that is not a usual target for pathogens. The plant possesses mechanisms highly effective including secondary metabolites, such as phenolics and saponin glycosides defense, which are not part of the defensive shackles of species, conferring an innate protection (Avello et al., 2009). Therefore, murta leaf and berry extracts have shown a strong topical anti-inflammatory activity in mice due to the presence of several pentacyclic triterpene acids, including the 2-a-hydroxy derivatives alphitolic, asiatic, and corosolic acids (Aguirre et al., 2006; Schreckinger et al., 2010; Arancibia-Radich et al., 2016).

It is known that polyphenols and many other natural antioxidants (vitamins, carotenoids and other endogenous constituents) may promote a better health. These antioxidants are capable of fulfilling a number of functional roles, acting as 
free radical scavengers, peroxide decomposers, singlet and triplet oxygen quenchers, enzyme inhibitors and synergists (Alfaro et al., 2013). Polyphenolic compounds are known to be useful in formulating nutritional or medicinal supplements for the treatment of several diseases. An important activity of polyphenols is the inhibition of digestive enzymes, especially carbohydrate-hydrolyzing enzymes such as R-amylase and R-glucosidase. Inhibitors of these enzymes are able to retard carbohydrate digestion, thus causing a reduction in glucose absorption rate. Effective R-amylase and
R-glucosidase polyphenol-type inhibitors from natural resources have been reported to be useful in reducing postprandial hyperglycemia (Rubilar et al., 2006).

Recent studies have focused on the phenolic composition of murta leaf extracts, where this extracts were particularly active in preventing the growth of Staphylococcus aureus, Pseudomonas aeruginosa, and Klebsiella pneumoniae bacteria (Aguirre et al., 2006; Schreckinger et al., 2010). Murta dry leaf extracts have also shown a nematicidal effect against the rot-knot nematode Meloidogyne hapla (Table 5), among other species

Table 5. Biological activities of fruits and leaves of murta

\begin{tabular}{|c|c|c|c|c|}
\hline Part used & Biological Property & Model & Dose & Reference \\
\hline $\begin{array}{l}\text { Leaves and } \\
\text { fruit }\end{array}$ & $\begin{array}{l}\text { Antimicrobial } \\
\text { activity }\end{array}$ & $\begin{array}{l}\text { P. aeruginosa, } \\
\text { K. pneumoniae } \\
\text { S. aureus }\end{array}$ & $\begin{array}{l}90 \mathrm{~mL} \text { of } 50: 50 \text { water:ethanol } \\
\text { extract. }\end{array}$ & Shene et al., 2009 \\
\hline \multirow[t]{12}{*}{ Leaves } & $\begin{array}{l}\text { Antiparasitic } \\
\text { activity }\end{array}$ & M. hapla & $\begin{array}{l}1 \%(w t / w t) \text { dry leaves in } \\
\text { sandy soil substrate. }\end{array}$ & Schreckinger et al., 2010 \\
\hline & \multirow[t]{3}{*}{ Analgesic effect } & \multirow[t]{3}{*}{ Mice } & $\begin{array}{l}\text { Intraperitoneal } \\
\text { administration: } \\
\mathrm{ED}_{50}=1.37 \mathrm{mg} / \mathrm{kg} \\
\text { methanol extract. }\end{array}$ & Delporte et al., 2007 \\
\hline & & & $\begin{array}{l}\text { Oral administration: } \\
\mathrm{ED}_{50}=199 \mathrm{mg} / \mathrm{kg} \\
\text { dichloromethane } \\
\text { extract. }\end{array}$ & Delporte et al., 2007 \\
\hline & & & $\begin{array}{l}\text { Topical administration: } \\
\mathrm{ED}_{50}=2 \% \\
\text { (wt/vol) dichloromethane } \\
\text { extract. }\end{array}$ & Delporte et al., 2007 \\
\hline & $\begin{array}{l}\text { Antioxidant } \\
\text { activity }\end{array}$ & Erythrocytes & 10 mM GAE. & Suwalsky et al., 2007 \\
\hline & $\begin{array}{l}\text { Topical } \\
\text { anti-inflammatory } \\
\text { activity }\end{array}$ & Mice & $1 \mathrm{mg}$ of leaf extract per ear. & Aguirre et al., 2006 \\
\hline & $\begin{array}{l}\text { Alteration } \\
\text { of human erythrocyte } \\
\text { morphology }\end{array}$ & $\begin{array}{l}\text { Human } \\
\text { erythrocytes }\end{array}$ & 1 mM GAE aqueous extract. & Suwalsky et al., 2006 \\
\hline & Antioxidant activity & Human trial & $\begin{array}{l}1 \% \text { (wt/vol) dry leaf infusion } \\
\text { consumed twice per day for } \\
3 \text { days. }\end{array}$ & Avello et al., 2009 \\
\hline & Antimicrobial activity & P. aeruginosa & $100 \%$ water, $40-60 \%$ & Avello et al., 2009 \\
\hline & & E. aerogenes & methanol/water & \\
\hline & & $\begin{array}{l}\text { S. aureus } \\
\text { C. albicans }\end{array}$ & and $100 \%$ methanol extracts. & \\
\hline & $\begin{array}{l}\text { Anti-inflammatory } \\
\text { activity }\end{array}$ & Mice ear edema & $\begin{array}{l}\text { Maximum effect of } 63.2 \% \text { at } \\
\text { the dose of } 20 \mathrm{mg} / \mathrm{kg} \mathrm{BW}\end{array}$ & $\begin{array}{l}\text { Arancibia-Radich et al., } \\
2016\end{array}$ \\
\hline \multirow[t]{2}{*}{ Fruit } & Cytotoxicity & $\begin{array}{l}\text { Cancer cells } \\
\text { (SW48 and HT-29) }\end{array}$ & $\begin{array}{l}200 \mathrm{~g} / \mathrm{ml} \text { ( } 50 \% \\
\text { Dimethylsulfoxide) of extract }\end{array}$ & Flis et al., 2012 \\
\hline & Apoptosis & $\begin{array}{l}\text { Human colorectal } \\
\text { cancer cells }\end{array}$ & $\begin{array}{l}72 \mathrm{~h} \text { of treatment in annexin } \\
\text { V-FITC kit. }\end{array}$ & Flis et al., 2012 \\
\hline
\end{tabular}

$\mathrm{ED}_{50}: 50 \%$ effective dose; GAE: gallic acid equivalent. 
(Schreckinger et al., 2010).

Besides, the effect of two different extractive solvents (water and 50/50 ethanol/water) on the growth of bacterium strains isolated from fecal samples was evaluated in vitro using disk diffusion tests. Isolates of sensitive gut bacteria were characterized through the partial sequence of $16 \mathrm{~S}$ rDNA gene and enzymatic profiles. Finally, to relate sensitivity to the extracts and enzymatic capability, the profiles were compared to those of lactic acid bacteria that were found to be resistant to murta extracts in a previous study (Shene et al., 2009). According to Shene et al. (2012) the average antimicrobial activity of penicillin was higher than that of the extracts. In general, the extracts and gentamicine exerted a similar antimicrobial activity. Murta extracts showed variable antimicrobial activity depending on both the strain and the solvent used for the extraction. The $50 / 50$ ethanol/water extract exerted, in general, a higher antimicrobial activity than that of the water extract (Shene et al., 2012).

\section{CONCLUSIONS}

Murta (Ugni molinae Turcz.) is not a widelyknown Chilean native species, but it has one of the richest sources of phenolic compounds with broad biological activities. This review has shown that murta berries and leaves have a rich and diversified composition of bioactive compounds, mainly phenolic compounds, where the main compounds found in berries and leaves are flavonoids (anthocyanins, flavonols, flavanols), condensed and hydrolyzable tannins, stilbenoids (resveratrol), and phenolic acids.

Moreover, most of the health attributes have been related to the phenolic compounds, therefore, murta leaf and berry extracts have proven to have shown a strong topical antiinflammatory activity, antimicrobial activity, an analgesic affect and have strong antioxidant activity.

The properties given by bioactive compounds coming from murta offer many opportunities for their use in food industry. Most of the health attributes have been related to the phenolic compounds, but other components, such as terpenes, may also result in health benefits. Finally, further studies are needed to understand the beneficial effects reported to date.

\section{ACKNOWLEDGEMENTS}

The authors thank the research office of the University of La Serena (DIULS) and FONDECYT (1140075) for the support provided.

\section{LITERATURE CITED}

Aguirre, M.C., C. Delporte, N. Backhouse, S. Erazo, M.E. Letelier, B.K. Cassels, et al. 2006. Topical anti-inflammatory activity of 2a-hydroxy pentacyclic triterpene acids from the leaves of Ugni molinae. Bioorg Med. Chem. 14:5673-5677.

Ah-Hen, K.S., A. Vega-Gálvez, N. Moraga, and R. Lemus-Mondaca. 2012. Modelling of rheological behaviour of pulps and purées from fresh and frozen-thawed murta (Ugni molinae Turcz.) Berries. Int. J. Food Eng. 8:122.

Ah-Hen, K.S., C.E. Zambra, J.E. Aguëro, A. Vega-Gálvez, and R. Lemus-Mondaca. 2013. Moisture diffusivity coefficient and convective drying modelling of murta (Ugni molinae Turcz.): Influence of temperature and vacuum on drying kinetics. Food Bioprocess Technol. 6:919-930.

Alfaro, S., A. Mutis, A. Quiroz, I. Seguel, and E. Scheuermann. 2014. Effects of drying techniques on murtilla fruit polyphenols and antioxidant activity. J. Food Res. 3:7382.

Alfaro, S., A. Mutis, R. Palma, A. Quiroz, I. Seguel, and E. Scheuermann. 2013. Influence of genotype and harvest year on polyphenol content and antioxidant activity in murtilla (Ugni molinae Turcz.) fruit. J. Soil Sci. Plant Nutr. 13:67-78.

Arancibia-Radich, J., M. Peña-Cerda, D. Jara, P. Valenzuela-Bustamante, L. Goity, G. Valenzuela-Barra, et al. 2016. Comparative study of anti-inflammatory activity and qualitative-quantitative composition of triterpenoids from ten genotypes of Ugni molinae. Bol. Latinoam. Caribe Plantas Med. Aromát. 15(5):274-287.

Arora, A., T. Byren, M. Nair, and G. Strasburg. 2000. Modulation of liposomal membrane fluidity by flavonoids and isoflavonoids. Arch. Biochem. Biophys. 373:102-109.

Augusto, T.R., E.S. Scheuermann Salinas, S.M. Alencar, M.A. D'arce, A. Costa de Camargo, and T.M. Vieira. 2014. Phenolic compounds and antioxidant activity of hydroalcoholic extracts of wild and cultivated murtilla (Ugni molinae Turcz.). Food Sci. Technol. (Campinas) 34:667-673.

Avello, M., and E. Pastene. 2004. Antioxidant activity of Ugni molinae Turcz. "Murtilla" infuses. Bol. Latinoam. Caribe Plantas Med. Aromát. 4:33-39. 
Avello, M., R. Valdivia, M.A. Mondaca, J.L. Ordoñez, M. Bittner, and J. Becerra. 2009. Activity of Ugni molinae Turcz. against microorganisms with clinical importance. Bol. Latinoam. Caribe Plantas Med. Aromát. 8(2):141-144.

Banno, N., T. Akihisa, H. Tokuda, K. Yasukawa, H. Higashihara, M. Ukiya, et al. 2004. Triterpene acids from the leaves of Perilla frutescens and their anti-inflammatory and antitumor-promoting effects. Biosci. Biotechnol. Biochem. 68(1):85-90.

Banno, N., T. Akihisa, H. Tokuda, K. Yasukawa, Y. Taguchi, H. Akazawa, et al. 2005. Antiinflammatory and antitumor-promoting effects of the triterpene acids from the leaves of Eriobotrya japonica. Biol. Pharm. Bull. 28(10):1995-1999.

Barreau, A., J.T. Ibarra, F.S. Wyndham, A. Rojas, and R.A. Kozak. 2016. How can we teach our children if we cannot access the forest? Generational change in mapuche knowledge of wild edible plants in Andean temperature ecosystems of Chile. J. Ethnobiol. 36(2):412432.

Basu, A., M. Rhone, and T.J. Lyons. 2010. Berries: Emerging impact on cardiovascular health. Nutr. Res. 68:168-177.

Benzie, I.F.F., and J.J. Strain. 1996. The ferric reducing ability of plasma (FRAP) as a measure of "antioxidant power": The FRAP assay. Anal. Biochem. 239(1):70-76.

Bifani, V., C. Ramírez, M. Ihl, M. Rubilar, A. García, and N. Zaritzky. 2007. Effects of murta (Ugni molinae Turcz.) extract on gas and water vapor permeability of carboxymethylcellulose-based edible films. LWT- Food Sci. Technol. 40:1473-1481.

Brito, A., C. Areche, B. Sepúlveda, E.J. Kennelly, and M.J. Simirgiotis. 2014. Anthocyanin characterization, total phenolic quantification and antioxidant features of some Chilean edible berry extracts. Molecules 19:1093610955.

Celli, G.B., A. Ghanem, and M.S.L. Brooks. 2014. Haskap berries (Lonicera caerulea L.)-a critical review of antioxidant capacity and health-related studies for potential valueadded products. Food Bioprocess Technol. 7:1541-1554.

Chacón-Fuentes, M., L. Parra, C. RodriguezSaona, I. Seguel, R. Ceballos, and A. Quiroz. 2015. Domestication in murtilla (Ugni molinae) reduced defensive flavonol levels but increased resistance against a native herbivorous insect. Environ. Entomol. 1-11.
Conde, C., P. Silva, N. Fontes, A. Dias, R. Tavares, M. Sousa, et al. 2007. Biochemical changes troughout grape berry development and fruit and wine quality. Global Science Books 1:122.

Davey, M.W., M. Van Montagu, D. Inze, M. Sanmartin, A. Kanellis, N. Smirnoff, et al. 2000. Plant L-ascorbic acid: Chemistry, function, metabolism, bioavailability and effects of processing. J. Sci. Food Agric. 80:825-860.

Delporte, C., N. Backhouse, V. Inostroza, M.C. Aguirre, N. Peredo, X. Silva, et al. 2007. Analgesic activity of Ugni molinae (murtilla) in mice models of acute pain. J. Ethnopharmacol. 112:162-165.

Dontha, S. 2016. A review on antioxidant methods. Asian J. Pharm. Clin. Res. 9 (2):14-32.

Durán, X., S. Saavedra, M. Bravo, and M. Gutiérrez. 2014. Formulation and physicochemical evaluation of vinegars produced from murta (Ugni molinae Turcz.) and maqui (Aristotelia chilensis (Molina) Stunz) with bees' honey (Apis mellifera L.) at laboratory scale. Boletim do CEPPA 32:167-176.

Erlund, I. 2004. Review of the flavonoids quercetin, hesperetin, and naringenin. Dietary sources, bioactivities, bioavailability, and epidemiology. Nutr Res. 24:851-874.

Flis, S., Z. Jastrzebski, J. Namiesnik, P. ArancibiaAvila, F. Toledo, H. Leontowicz, et al. 2012. Evaluation of inhibition of cancer cell proliferation in vitro with different berries and correlation with their antioxidant levels by advanced analytical methods. J. Pharm. Biomed. Anal. 62:68-78.

Foncea, R., C. Carvajal, and F. Leighton. 2000. Endothelial cell oxidative stress and signal transduction. Biol. Res. 33:86-96.

Fredes, C. 2009. Antioxidants in Chilean native berries. Bol. Latinoam. Caribe Plantas Med. Aromát. 8(6):469-478.

Gironés-Vilaplana, A., N. Baenas, D. Villaño, and D.A. Moreno. 2014. Iberian-american fruits rich in bioactive phytochemicals for nutrition. LIMENCOP S.L. First Edition. Alicante, Spain.

Goity, L.E., M.J. Qieupil, D. Jara, S.E. Alegría, M. Peña, A. Barriga, et al. 2013. An HPLC-UV and HPLC-ESI-MS based method for identification of anti- inflammatory triterpenoids from the extracts of Ugni molinae. Bol. Latinoam. Caribe Plantas Med. Aromát. 12:108-116.

Gómez-Guillén, M.C., M. Ihl, V. Bifani, A. Silva, and P. Montero. 2007. Edible films made from tuna-fish gelatin with antioxidant extracts of two different murta ecotypes leaves (Ugni molinae Turcz.). Food Hydrocoll. 21:11331143. 
González, G. 2009. Libro de valorización: resultados y lecciones en productos agroindustriales ricos en antioxidantes, a base de berries nativos. Fundación para la Innovación Agraria (FIA), Santiago, Chile.

Gorinstein, S., P. Arancibia-Avila, F. Toledo, J. Namieśnik, H. Leontowicz, M. Leontowicz, et al. 2013. Application of analytical method for the determination of bioactive compounds in some berries. Food Anal. Methods. 6:432-444.

Harbone, J.B., and C.A. Williams. 2000. Advances in favonoid research since 1992. Phytochemistry 55:481-504.

Hauser, C.A., A. Peñaloza, F. Rodríguez, A. Guarda, and M.J. Galotto. 2014. Promising antimicrobial and antioxidant extracts of murta leaves (Ugni molinae Turcz.): Shelf-life extension and food safety. Food Packaging and Shelf Life 1:77-85.

Heinonen, M. 2007. Antioxidant activity and antimicrobial effect of berry phenolics - a Finnish perspective. Mol. Nutr. Food Res. 51:684-691.

Iqbal, K., A. Khan, and M.M.A.K. Khattak. 2004. Biological significance of ascorbic acid (vitamin C) in human health - a review. Pak. J. Nutr. 3:5-13.

Jimenez-Garcia, S.N., R.G. Guevara-Gonzalez, R. Miranda-Lopez, A.A. Feregrino-Perez, I. Torres-Pacheco, and M.A. Vazquez-Cruz. 2013. Functional properties and quality characteristics of bioactive compounds in berries: Biochemistry, biotechnology, and genomics. Food Res. Int. 54:1195-1207.

Junqueira-Gonçalves, M.P., L. Yáñez, C. Morales, M. Navarro, R.A. Contreras, and G.E. Zúñiga. 2015. Isolation and characterization of phenolic compounds and anthocyanins from murta (Ugni molinae Turcz.) fruits. Assessment of antioxidant and antibacterial activity. Molecules 20:5698-5713.

Lambert, I.H., E.K. Hoffmann, and S.F. Pedersen. 2008. Cell volume regulation: Physiology and pathophysiology. Acta Physiol. 194:255-282.

Lee, S.K., and A.A. Kader. 2000. Preharvest and postharvest factors influencing vitamin C content of horticultural crops. Postharvest Biol. Tec. 20:207-220.

Merino, F.S., 2002. Elaboración de láminas de fruta ("fruit leathers") a partir de pulpa de murta (Ugni molinae Turcz.) congelada. Tesis Licenciado en Ingeniería en Alimentos, University Austral de Chile, Valdivia, Chile.
Moraga J.A., 2008. Determinación del calor específico de murta (Ugni molinae Turcz) y arándano (Vaccinium corymbosum L.) en un rango de temperatura entre $20^{\circ} \mathrm{C}$ y $80^{\circ} \mathrm{C}$ por el método de la calorimetría diferencial de barrido. Tesis Licenciado en Ciencia de los Alimentos. Universidad Austral de Chile, Valdivia, Chile.

Morgan, K., 2008. Nutritional determinants of bone health. J. Nutr. Elder. 27:3-27.

Paredes-López, O., M.L. Cervantes-Ceja, M. Vigna-Pérez, and T. Hernández-Pérez. 2010. Berries: Improving human health and healthy aging, and promoting quality life $-\mathrm{A}$ review. Plant Food Hum. Nutr. 65:299-308.

Peña-Cerda, M., J. Arancibia-Radich, P. Valenzuela-Bustamante, R. Pérez-Arancibia, A. Barriga, I. Seguel, et al. 2016. Phenolic composition and antioxidant capacity of Ugni molinae Turcz. leaves of different genotypes. Food Chem. 215:219-227.

Puente-Díaz, L., K. Ah-Hen, A. Vega-Gálvez, R. Lemus-Mondaca, and K. Di Scala. 2013. Combined infrared-convective drying of murta (Ugni molinae Turcz.) berries: Kinetic modeling and quality assessment. Dry Technol. 31:329-338.

Ramirez, J.E., R. Zambrano, B. Sepúlveda, E.J. Kennelly, and M.J. Simirgiotis. 2015. Anthocyanins and antioxidant capacities of six Chilean berries by HPLC-HR-ESI-ToFMS. Food Chem. 176:106-114.

Renkema, K.Y., R.T. Alexander, R.J. Bindels, and J.G. Hoenderop. 2008. Calcium and phosphate homeostasis: Concerted interplay of new regulators. Ann.Med. 40:82-91.

Retamales, H.A., R. Scherson, and T. Scharaschkin. 2014. Foliar micromorphology and anatomy of Ugni molinae Turcz. (Myrtaceae), with particular reference to schizogenous secretory cavities. Rev. Chil. Hist. Nat. 87:27 1-7.

Rodríguez, K., K. Ah-Hen, A. Vega-Gálvez, J. López, I. Quispe-Fuentes, R. LemusMondaca, et al. 2014. Changes in bioactive compounds and antioxidant activity during convective drying of murta (Ugni molinae T.) berries. Int. J. Food Sci. Tech. 49:990-1000.

Romaní, A., P. Pinelli, N. Mulinacci, F. Vincieri, and M. Tattini. 1999. Identification and quantitation of polyphenols in leaves of Myrtus communis L. Chromatographia. 49:17-20.

Rubilar, M., C. Jara, Y. Poo, F. Acevedo, C. Gutierrez, J. Sineiro, et al. 2011. Extracts of maqui (Aristotelia chilensis) and murta (Ugni molinae Turcz.): Sources of antioxidant compounds and r-glucosidase/ r-amylase inhibitors. J. Agric. Food Chem. 59:630-1637. 
Rubilar, M., M. Pinelo, M. Ihl, E. Scheuermann, J. Sineiro, and M.J. Nuñez. 2006. Murta leaves (Ugni molinae Turcz.) as a source of antioxidant polyphenols. J. Agric. Food Chem. 54:59-64.

Ruiz, A., I. Hermosín-Gutiérrez, C. Mardones, C. Vergara, E. Herlitz, M. Vega, et al. 2010. Polyphenols and antioxidant activity of calafate (Berberis microphylla) fruits and other native berries from Southern Chile. J. Agric. Food Chem. 58:6081-6089.

Ruiz, M., 2008. Compuestos fenólicos en frutos de calafate (Berberis microphylla) y comparación de su capacidad antioxidante con otros berries del sur de Chile. Tesis Bioquímico, University of Concepción, Concepción, Chile.

Scheuermann, E., I. Seguel, A. Montenegro, R.O. Bustos, E. Hormazábal, and A. Quiroz. 2008. Evolution of aroma compounds of murtilla fruits (Ugni molinae Turcz.) during storage. J. Sci. Food Agric. 88:485-492.

Schmidt-Hebbel, H., I. Pennacchiotti, L. Masson, and M.A. Mella. 1990. Tabla de composición química de los alimentos chilenos. $8^{\text {a. ed. }}$ Editorial Antártica S.A., Santiago, Chile.

Schreckinger, M.E., J. Lotton, M.A. Lila, and E. Gonzalez de Mejia. 2010. Berries from South America: A comprehensive review on chemistry, health potential, and commercialization. J. Med. Food. 13:233-246.

Seeram, N. 2008. Berry fruits: compositional elements, biochemical activities, and the impact of their intake on human health, performance, and disease. J. Agric. Food Chem. 56:627-629.

Seguel, I., E. Peñaloza, and N. Gaete. 2000. Colecta y caracterizacion molecular de germoplasma de murta (Ugni molinae Turcz.). en Chile. Agro Sur 28(2):32-41.

Shene, C., N. Canquil, M. Jorquera, M. Pinelo, M. Rubilar, F. Acevedo, et al. 2012. In vitro activity on human gut bacteria of murta leaf extracts (Ugni molinae Turcz.), a native plant from Southern Chile. J. Food Sci. 77:323-329.

Shene, C., A.K. Reyes, M. Villarroel, J. Sineiro, M, Pinelo, and M. Rubilar. 2009. Plant location and extraction procedure strongly alter the antimicrobial activity of murta extracts. Eur. Food Res. Technol. 228:467-475.
Shih-Li, H., H. Chin-Lin, and Y. Gow-Chin. 2006. Growth inhibitory effect of quercetin on SW 872 human liposarcoma cells. Life Sci. 79:203209.

Skrovankova, S., Sumczynski, D., Mlcek, J., T. Jurikova, and J. Sochor. 2015. Bioactive compounds and antioxidant activity in different types of berries. Int. J. Mol. Sci. 16:24673-24706

Speisky, H., C. López-Alarcón, M. Gómez, J. Fuentes, and C. Sandoval-Acuña. 2012. First web-based database on total phenolics and oxygen radical absorbance capacity (ORAC) of fruits produced and consumed within the South Andes Region of South America. J. Agric. Food Chem. 60:8851-8859.

Suwalsky, M., and M. Avello. 2014. Antioxidant capacity of Ugni molinae fruit extract on human erythrocytes: An in vitro study. J. Membr. Biol. 247:703-712.

Suwalsky, M, P. Orellana, M. Avello, and F. Villena. 2007. Protective effect of Ugni molinae Turcz. against oxidative damage of human erythrocytes. Food Chem. Toxicol. 45:130-135.

Suwalsky, M., P. Orellana, M. Avello, F. Villena, and C.P. Sotomayor. 2006. Human erythrocytes are affected in vitro by extracts of Ugni molinae leaves. Food Chem. Toxicol. 44:1393-1398.

Taboada, E., P. Fisher, R. Jara, E. Zúñiga, M. Gidekel, JC. Cabrera, et al. 2010. Isolation and characterisation of pectic substances from murta (Ugni molinae Turcz.) fruits. Food Chem. 123:669-678.

Torres, A.P., I.B. Seguel, G.J. Contreras, and M.E. Castro. 1999. Physico-chemical characterization of murta (murtilla) fruit (Ugni molinae Turcz.). Agric. Téc. 59:260-270.

Wen, X., H. Sun, J. Liu, K. Cheng, P. Zhang, L. Zhang, et al. 2008. Naturally occurring pentacyclic triterpenes as inhibitors of glycogen phosphorylase: Synthesis, structure-activity relationships, and X-ray crystallographic studies. J. Med. Chem. 51:3540-3554. 